\title{
CHANGES IN THE CYTOKINE LEVELS IN ADOLESCENTS WITH GINGIVITIS AFTER TREATMENT WITH PROPOLIS
}

\author{
STELA PEYCHEVA ${ }^{1}$, ELISAVETA APOSTOLOVA ${ }^{2 *}$, ZHIVKO PEYCHEV ${ }^{3}$, PETYA GARDJEVA ${ }^{4}$, \\ ANTON SLAVOV ${ }^{5}$, MARIANNA MURDJEVA ${ }^{4}$ \\ ${ }^{I}$ Department of Paediatric Dental Medicine, Faculty of Dental Medicine, Medical University-Plovdiv, 15A Vassil Aprilov \\ Blvd. 4002, Plovdiv, Bulgaria. \\ ${ }^{2}$ Department of Pharmacology and Drug Toxicology, Faculty of Pharmacy, Medical University-Plovdiv, 15A Vassil Aprilov \\ Blvd. 4002, Plovdiv, Bulgaria. \\ ${ }^{3}$ Department of Medical Informatics, Biostatistics and e-learning, Faculty of Public Health, Medical University-Plovdiv, 15A \\ Vassil Aprilov Blvd. 4002, Plovdiv, Bulgaria. \\ ${ }^{4}$ Department of Microbiology and Immunology, Faculty of Pharmacy, Medical University-Plovdiv, 15A Vassil Aprilov Blvd. \\ 4002, Plovdiv, Bulgaria. \\ ${ }^{5}$ Department of Organic and Inorganic Chemistry, Faculty of Technology, University of Food Technologies-26 Maritsa \\ Blvd., Plovdiv 4000, Bulgaria.
}

*corresponding author: apostolova1212@gmail.com

Manuscript received: October 2018

\begin{abstract}
The aim of this study was to determine the effect of two treatment approaches on the levels of IL-1 $\beta$, TNF- $\alpha$, IL- 6 , IL-17A, IL-18, and IFN- $\gamma$ in the gingival crevicular fluid (GCF) in adolescents with moderate gingivitis. The participants were divided randomly into two groups $(\mathrm{n}=35)$ as follows: group A - instructed to use marketed toothpaste, and group AP instructed to add 10 drops of Propolin ${ }^{\circledR}$ to the toothpaste before every brushing. Samples of GCF were collected at the first visit and on the $20^{\text {th }}$ day of the study. Enzyme-linked immunosorbent assays (ELISA) were used for the assay of each cytokine concentration. We detected a significant reduction in the levels of IL-1 $\beta$ ( $p<0.01)$, TNF- $\alpha(p<0.01)$, IL-18 (p $<$ $0.05)$ and INF- $\gamma(\mathrm{p}<0.01)$ in group A on the $20^{\text {th }}$ day in comparison to the initial levels. Participants in group AP registered significantly lower levels of IL-1 $\beta$ ( $p<0.001)$, IL-6 ( $p<0.001)$, TNF- $\alpha(p<0.001)$, IL-17A $(p<0.05)$, IL-18 (p $<0.01)$, IFN- $\gamma(\mathrm{p}<0.001)$. Comparing the cytokine levels in the groups on the $20^{\text {th }}$ day of the treatment, we registered significantly lower levels of IL-1 $\beta(p<0.05)$ and IL-18 $(p<0.05)$ in group AP when compared to group A. IL-18 and IL-1 $\beta$ could be used as inflammatory biomarkers in adolescents with gingivitis. The addition of propolis to the toothpaste resulted in a reduction of the gingival inflammation in adolescents with moderate gingivitis and greater gingival health improvement than the sole use of a toothpaste.
\end{abstract}

\section{Rezumat}

Scopul acestui studiu a fost determinarea efectului a două abordări terapeutice asupra nivelurilor de IL-1 $\beta$, TNF- $\alpha$, IL-6, IL17A, IL-18 și IFN- $\gamma$ în lichidul crevicular gingival (GCF) la adolescenți cu gingivită moderată. Subiecții au fost împărțiţi aleatoriu în două grupuri $(n=35)$, după cum urmează: grupul A - instruit să utilizeze doar pastă de dinți și grupul AP instruit să adauge 10 picături de Propolin ${ }^{\circledR}$ pe pasta de dinți înainte de fiecare periaj. Eșantioane de GCF au fost colectate la prima vizită şi în a 20 -a zi a studiului. Pentru determinarea fiecărei concentrații de citokine s-au utilizat teste ELISA. S-a observat o reducere semnificativă a nivelurilor de IL-1 $\beta(p<0,01)$, TNF- $\alpha(p<0,01)$, IL-18 $(p<0,05)$ și INF- $\gamma(p<0,01)$. Grupul AP a raportat valori semnificativ mai scăzute ale IL-1 $\beta(p<0,001)$, IL-6 (p < 0,001), TNF-a (p $<0,001)$, IFN-y (p $<0,001)$. Comparând nivelurile citokinelor din ziua a 20 -a, s-au înregistrat niveluri semnificativ mai scăzute de IL-1 $1 \beta$ (p $<$ $0,05)$ și IL-18 ( $<$ 0,05) în grupul AP comparativ cu grupul A. IL-18 și IL-1 $\beta$ ar putea fi utilizaţi ca biomarkeri inflamatorii la adolescenții cu gingivită. Adăugarea propolisului a determinat o reducere a inflamației gingivale.

Keywords: IL-1 $\beta$, TNF- $\alpha$, IL-6, IL-18

\section{Introduction}

Gingivitis is an inflammatory disease that affects and is limited to the gingival epithelium and fibrous connective tissues. This disease is a result of the interaction between the human organism and the microbial biofilm [5]. The inflammation, induced by the microbial biofilm (plaque) elicits an immune response in the host, mediated by neutrophils, macrophages/monocytes, and lymphocytes. These cells and the resident gingival cells release cytokines, which induce inflammation and disease progression $[5,18]$.

The $\mathrm{T}$ helper type 1 cells (Th1) play a critical role in the immune response $[18,15]$. Interferon $\gamma$ (IFN$\gamma)$ and interleukin-2 released by them activate macrophages, natural killer cells (NK) and 
cytotoxic $\mathrm{CD}^{+} \mathrm{T}$ cells [16]. They produce also interleukin-17 (IL-17), which is shown to activate epithelial, endothelial cells and fibroblasts and induce synthesis and release of interleukin-6 (IL-6) in these cells [18]. IL-6 is involved in the process of bone resorption and periodontitis [14].

At the initial phase of inflammation, immediately after microbial recognition, the immune cells release cytokines such as interleukin-1 (IL-1) and tumour necrosis factor alpha (TNF- $\alpha)$. TNF- $\alpha$ increases the production of pro-inflammatory cytokines e.g. interleukin 1 beta (IL-1 $\beta$ ) and IL-6 with a critical role in the osteoclastogenesis and bone loss [9]. The IL-1 $\beta$ is a part of the interleukin1 gene family and is also involved in the gingival inflammation [8].

Interleukin-18 (IL-18) also belongs to the interleukin-1 family and could be produced by NK and T-cells. IL-18 and interleukin-12 stimulate INF- $\gamma$ synthesis and release and is also involved in the gingival inflammation $[18,15]$.

Recent reports show the increasing interest in the natural products for the treatment of oral inflammatory diseases [6, 21]. Propolis is a bee product, which antibacterial, antifungal, antiviral, antitumor, immunomodulatory and antiinflammatory properties are extensively reported $[1,11,19]$.

The aim of this study was to determine the effect of two treatment approaches on the levels of six cytokines (IL-1 $\beta$, TNF- $\alpha$, IL-6, IL-17A, IL-18, and IFN- $\gamma$ ) in gingival crevicular fluid (GCF) in adolescents with gingivitis. We compared the efficacy of a marketed toothpaste to the addition of Bulgarian propolis to the same toothpaste.

\section{Materials and Methods}

The study design was approved by the Ethics Committee of the Medical University - Plovdiv, Bulgaria (approval number: 3/12.10.2010). The protocol was conducted in accordance with the Declaration of Helsinki and Tokyo, Good Clinical Practice guidelines, and national laws after a written informed consent was signed by the parents and verbal consent was obtained from the subjects. The propolis extract with the trade name Propolin ${ }^{\circledR}$ and the toothpaste "Astera parodont active" ${ }^{\circledR}$ are officially registered by the Bulgarian Drug Agency. They were obtained from a local pharmacy.

Subjects

A preliminary screening for plaque-induced gingivitis in 1391 students at the Humanitarian High School "St. St. Cyril and Methodius" in Plovdiv, Bulgaria was conducted and the gingival disease was diagnosed in 531 students. The initial examination consisted of the evaluation of the oral health as instructed $\mathrm{b}$ y WHO and described by
Petersen et al. [17]. The gingival index (GI) was estimated, as described by Löe [13].

The participants' selection was based on the following criteria:

Inclusion criteria: 1) physically and mentally healthy children; 2) age between 12 and 18 years; 3) patients of both genders; 4) diagnosis of moderate gingival inflammation (GI=1.1 - 2.0).

Exclusion criteria: 1) treatment with an orthodontic appliance; 2) severe deformities of jaws and teeth; 3) severe plaque-induced gingivitis; 4) smokers.

The selected adolescents were asked for consent and subsequently, a total of 70 high-school students were included in the study. Carious lesions were treated, poor dental restorations were corrected and calculus was removed, if present.

Study design

At the first visit, the gingival margin of mandibular central incisors was isolated from saliva for three minutes. Five $\mu \mathrm{L}$ GCF were collected from each participant using sterile curettes. The samples were sent immediately to the Department of Microbiology and Immunology, Faculty of Pharmacy at the Medical University in Plovdiv. They were frozen at $-70^{\circ} \mathrm{C}$ until the day of the analysis. Samples contaminated with blood or saliva were excluded.

After the sample collection, all subjects received a toothbrush and the toothpaste "Astera parodont active" ${ }^{\circledR}$, containing water, sorbitol, hydrated silica, PEG-8, aluminum lactate, sodium lauryl sulphate, cellulose gum, aroma, limonene, sodium monofluorophosphate, zinc citrate, titanium dioxide, polyvinylpyrrolidone, sodium saccharin, allantoin, methylparaben, triclosan and CI 12490. All participants were instructed to brush the teeth according to Bass technique for 2.5 to 3 minutes two times daily (in the morning and in the evening). The participants were divided randomly into two groups $(\mathrm{n}=35)$ as follows: first group (A) was instructed to use solely the provided toothpaste, and second group (AP), who were instructed to add 10 drops of Propolin ${ }^{\circledR}$ (equivalent to $2.5 \mathrm{mg}$ Bulgarian propolis) to the amount of toothpaste used for every brushing. $\quad$ Propolin $^{\circledR} \quad$ (standardized 20\% hydroalcoholic extract of Bulgarian propolis) was purchased from the market and each participant in AP group received one vial of it.

In the $20^{\text {th }}$ day of the study, GCF samples were obtained according to the method, described above. Cytokine analysis

On the day of the analysis, the samples were thawed at room temperature. Then $350 \mu \mathrm{L}$ of phosphate-buffered saline (PBS, $\mathrm{pH}$ 7.2) were added to the tubes and they were gently shaken for $1 \mathrm{~min}$. The samples were centrifuged at $2000 \mathrm{~g}$ for $5 \mathrm{~min}$ in order to elute GCF components completely. The supernatant was divided into 6 
FARMACIA, 2019, Vol. 67, 2

aliquots for the determination of each cytokine. Enzyme-linked immunosorbent assays (ELISA) specific for each cytokine (BioSource, Medgenics Diagnostics, Fleurus, Belgium) were performed according to the manufacturer's instructions.

ELISA reader (TECAN group, Männedorf, Switzerland) was used for optical density detection at the wavelength 450 and $620 \mathrm{~nm}$.

Chemical analysis of propolis extract (Propolin ${ }^{\circledR}$ ) In order to investigate the composition of Propolin ${ }^{\circledR}$ furthermore chromatographic analyses were performed. The total polyphenol content was determined as described by Slavov et al. with Folin-Ciocalteu's reagent (Sigma-Aldrich, Steinheim, Germany) [20]. Gallic acid was employed as calibration standard and the results were expressed as gallic acid equivalents (GAE) per $\mathrm{mL}$ propolis extract. Total flavonoids were determined using $\mathrm{Al}\left(\mathrm{NO}_{3}\right)_{3}$ reagent (Sigma-Aldrich, Steinheim, Germany) and measuring the absorbance at $415 \mathrm{~nm}$ as described in Slavov et $a l$. and the results were expressed as mg quercetin equivalents $(\mathrm{QE})$ per $\mathrm{mL}$ propolis extract.

The individual polar metabolites in the propolis extract were determined according to the following procedure: $0.2 \mathrm{~mL}$ extract was lyophilized and 50 $\mu \mathrm{L}$ pyridine and $50 \mu \mathrm{L}$ N,O-bis-(trimethylsilyl)trifluoro-acetamide (BSTFA) were added. The sample was incubated at $70^{\circ} \mathrm{C}$ for $40 \mathrm{~min}$. For analysis $1.0 \mu \mathrm{L}$ from the solution was injected on gas chromatograph Agilent GC 7890 with masselective detector Agilent MD 5975 and column HP-5ms (30 m with diameter $0.32 \mathrm{~mm}$ and $0.25 \mu \mathrm{m}$ thicknesses). The following temperature regimen was used: initial temperature $100^{\circ} \mathrm{C}$ (hold for 2 min) then increased to $180^{\circ} \mathrm{C}$ with $15^{\circ} \mathrm{C} / \mathrm{min}$ (hold for $1 \mathrm{~min}$ ) and increase of the temperature to $300^{\circ} \mathrm{C}$ with $5^{\circ} \mathrm{C} / \mathrm{min}$ (hold for $10 \mathrm{~min}$ ); injector and detector temperatures $-250^{\circ} \mathrm{C}$, helium was used as carrier gas at a flow rate $1.0 \mathrm{~mL} / \mathrm{min}$. The scanning range of mass-selective detector was $\mathrm{m} / \mathrm{z}=50-550$ in split-split mode (10:1).

All the analyses were performed in triplicate and the results were given as mean $\pm \mathrm{SD}$.

Statistics

Statistical analysis was performed using SPSS v 17 statistical software (SPSS, Inc., Chicago, IL, USA). The One sample Kolmogorov-Smirnov test showed normal data distribution. The cytokine levels between the two groups were compared with Independent samples T-test. Paired samples T-test was used for the comparison of the two therapeutic approaches before and after treatment. T-scores were recorded. P-values under 0.05 were considered statistically significant.

\section{Results and Discussion}

The present study demonstrated similar concentrations of all tested cytokines before treatment. This result is not surprising given the same diagnosis and stage of gingival inflammation of the participants. Moreover, a critical requirement for the experiment is the statistical homogeneity of the tested subjects. The gingival inflammation results in elevated levels of IL-1 $\beta$, IL- 8 , TNF- $\alpha$, prostaglandin 2 and matrix metalloproteinases $[3,23]$. In our study, we chose IL-1 $\beta$, IL-6, TNF- $\alpha$, IL-17A, IL-18, and INF- $\gamma$ as biomarkers of gingival inflammation.

The changes in the levels of IL-1 $\beta$, IL- 6, TNF- $\alpha$, IL-17A, IL-18, and INF- $\gamma$ are shown in Figures 1,2 and 3 .
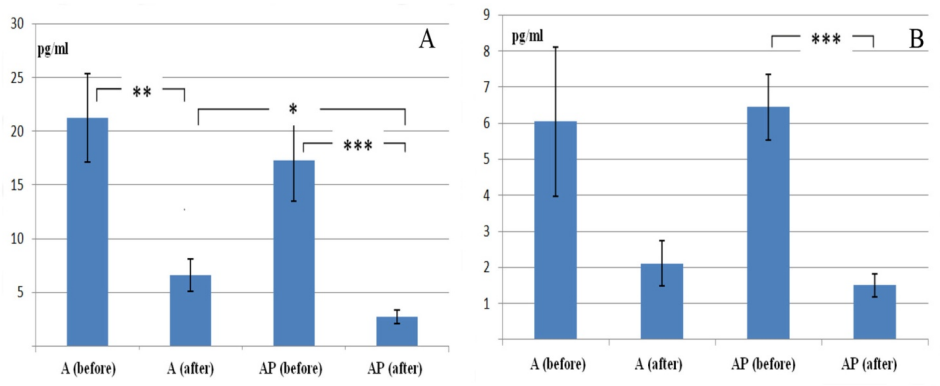

Figure 1.

Mean concentrations ( \pm SEM) of IL-1 $\beta$ (A) and IL-6 (B) in gingival crevicular fluid before and after 20 days of treatment with toothpaste (A) or toothpaste + propolis (AP); ${ }^{*} \mathrm{p}<0.05 ; * * \mathrm{p}<0.01 ; * * * \mathrm{p}<0.001$.

The role of IL-1 $\beta$ in the gingival inflammation has been discussed by other authors $[8,12,15]$. They reported increased levels of IL-1 in GCF of patients with gingivitis. Even though the cytokine could be detected in healthy sites, it was shown that its levels rise with the development of gingivitis. Our results confirm this statement and IL-1 $\beta$ could be detected in both groups on the $20^{\text {th }}$ day of the treatment even though the number of adolescents with GI $=1.1$ 2.0 was significantly reduced (data not shown). Previously, we studied the influence of the propolis addition to the toothpaste on the microbial flora and observed complete eradication of some oral pathogens (unpublished results). IL-1 $\beta$ could also 
be produced by gingival fibroblasts in response to bacterial stimulation [8] and the complete eradication of some oral pathogens provide a possible explanation of the registered decrease of its concentrations in group AP. Moreover, at the end of the study, the concentration of IL- $1 \beta$ in group AP was significantly lower than group A and this result could be related to the absence of bacterial stimulation for its release in group AP. IL$1 \beta$, IL- 6 , and TNF- $\alpha$ are the first cytokines released after microbial stimulation and among them, IL-1 $\beta$ and IL-6 play a major role in the cell migration to the inflamed sites [9]. Noh et al. [14] also reported increased IL-6 concentration in inflamed tissues (patients with periodontitis). In our study, both approaches led to decrease in the IL-6 levels, however, statistical significance was detected solely in group AP. Given the complex composition of propolis, we assumed that some of its components are responsible for this effect. Woo et al. [22] reported that chrysin (a flavonoid) suppress the nuclear factor for IL-6. However, the role of other components could not be excluded.

The presence of specific compounds (or classes of compounds) differentiates various propolis types and also their biological activities.

Propolin ${ }^{\circledR}$ was found to be a rich source of aromatic acids and their derivatives, derivatives of cinnamic

acid, flavonoids, terpenes and fatty acids (Table I). Studies investigating the biological activities of propolis revealed that these types of compounds were involved in the antimicrobial, antioxidant, anticaries, antiinflamatory activities of propolis [19]. The analyses suggested that the propolis extract used in the clinical studies exhibited high total polyphenolic and flavonoid content (13.62 \pm $0.34 \mu \mathrm{mol} \mathrm{GAE} / \mathrm{mL}$ and $10.28 \pm 0.32 \mu \mathrm{mol}$ $\mathrm{QE} / \mathrm{mL}$, respectively). Generally, it is recognized that propolis from moderate climatic zones (Europe, North America and the non-tropical regions of Asia) originate mainly from Populus species and hybrids, and are rich in flavonoids, phenolic acids and their esters which often are used as markers for propolis identification [2]. The results from the analysis suggested that the propolis extract was poplar type.

Hazem et al. reported that the antimicrobial action of propolis could be related to the presence of flavones, flavanones, phenolic acids, and phenolic acid esters [10]. Galangin, pinocembrin, chrysin, and caffeic acid esters are the main substances, which determine the antimicrobial effect of propolis. Of all the chemical agents present in propolis, galangin (3,5,7-trihydroxyflavone) was reported to be one of the most active antibacterial agents [10].

Table I

Polar compounds in propolis extract

\begin{tabular}{|c|c|c|c|}
\hline \multirow{2}{*}{ RI } & \multirow{2}{*}{ Compound } & \multirow{2}{*}{ Class } & Propolis extract Propolin $^{(B)}$ \\
\hline & & & $\%$ of total ion current \\
\hline 2139 & Caffeic acid & Hydroxycinnamic acid & $55.16 \pm 1.12$ \\
\hline 2544 & 5,7-Dihydroxyflavanone (Pinocembrin) & Flavanone & $45.63 \pm 0.68$ \\
\hline 2882 & 1,3,8-Trihydroxy-6-methylanthraquinone & Anthraquinone & $38.28 \pm 0.88$ \\
\hline 2701 & 5,7-Dihydroxyflavone (Chrysin) & Flavone & $31.50 \pm 0.99$ \\
\hline 2080 & 3,4,5-Trihydroxybenzoic acid ethyl ester & Ester & $30.50 \pm 1.01$ \\
\hline 2209 & $\alpha$-Linolenic acid & Fatty acid & $28.61 \pm 1.04$ \\
\hline 2855 & 4',5,7-Trihydroxyflavanone (Apigenin) & Flavone & $28.16 \pm 0.85$ \\
\hline 2870 & 3,5,7-Trihydroxyflavone (Galangin) & Flavonol & $26.61 \pm 1.04$ \\
\hline 2202 & Linoleic acid & Fatty acid & $22.99 \pm 0.96$ \\
\hline 3315 & $\begin{array}{r}\text { Stigmasterol } \\
\end{array}$ & Phytosterol & $15.25 \pm 1.12$ \\
\hline 2069 & 4-Hydroxy-3-methoxy-Cinnamic acid (Ferulic acid) & Hydroxycinnamic acid & $9.31 \pm 0.78$ \\
\hline 3355 & $\beta$-Sitosterol & Phytosterol & $7.86 \pm 0.92$ \\
\hline 1920 & p-Coumaric acid & Hydroxycinnamic acid & $7.11 \pm 0.55$ \\
\hline 2074 & 3-Hydroxy-4-methoxy-Cinnamic acid iso-Ferulic acid) & Hydroxycinnamic acid & $6.08 \pm 0.79$ \\
\hline 2032 & \begin{tabular}{|l|} 
3,4-Dimethoxycinnamic acid \\
\end{tabular} & Hydroxycinnamic acid & $5.75 \pm 0.75$ \\
\hline 1222 & Benzoic acid & Aromatic acid & $4.56 \pm 0.58$ \\
\hline 2755 & Caffeic acid phenetyl ester & Ester & $2.54 \pm 0.14$ \\
\hline 1393 & Hydroquinone & Phenol & $1.55 \pm 0.12$ \\
\hline 1498 & Vanillin & Aldehyde & $0.99 \pm 0.09$ \\
\hline 1526 & trans-Cinnamic acid & Cinnamic acid & $0.82 \pm 0.08$ \\
\hline 1813 & Protocatechuic acid & Aromatic acid & $0.79 \pm 0.08$ \\
\hline 1662 & 2,5-Dihydroxyacetophenone & Ketone & $0.68 \pm 0.06$ \\
\hline 1396 & Hydrocinnamic acid & Hydroxycinnamic acid & $0.62 \pm 0.04$ \\
\hline 1617 & p-Hydroxybenzoic acid & \begin{tabular}{|l|} 
Aromatic acid \\
\end{tabular} & $0.47 \pm 0.08$ \\
\hline 1555 & m-Hydroxybenzoic acid & Aromatic acid & $0.35 \pm 0.07$ \\
\hline
\end{tabular}

The results were presented as mean $\pm \mathrm{SD}$, RI: relative index (Kovats retention index) 
TNF- $\alpha$ is also involved in the inflammation and could induce the production of IL-1 $\beta$ and IL-6 [9]. In our experiment, decreased concentrations were detected in both study groups (A and AP) on the $20^{\text {th }}$ day. Higher levels of this cytokine in GCF in gingivitis were reported also by other authors, as reviewed by Boronat-Catalá et al. [4].

IL-17 also could induce the production and release of proinflammatory cytokines. It also leads to the activation of metalloproteinases [24]. This interleukin, TNF- $\alpha$, and IL-1 are involved in the chronic inflammatory response. IL-17 consists of six cytokines, named as A, B, C, D, E and F. IL$17 \mathrm{~A}$ is involved in the neutrophil infiltration of inflamed tissues and the host defense. However, higher concentrations are involved in the excessive inflammation and tissue destruction. IL-17 is produced by $\mathrm{T}$-cells after their differentiation to Th17 cells [24]. The differentiation is triggered by IL-6 (and transforming growth factor-beta). We found no statistical difference in the levels of both cytokines (IL-6 and IL-17A) in group A after the treatment in comparison to the initial levels. In contrast, the addition of propolis led to significant decrease of the concentrations of IL-6 and IL-17A. Probably the reduction in the IL- 6 levels is one of the factors for the reduced IL-17A concentration at the end of the study.
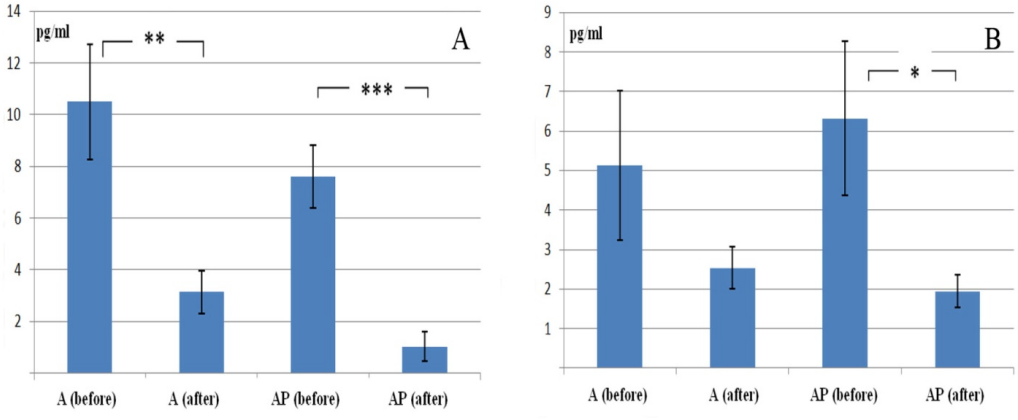

Figure 2.

Mean concentrations ( \pm SEM) of TNF- $\alpha$ (A) and IL-17A (B) in gingival crevicular fluid before and after 20 days of treatment with toothpaste (A) or toothpaste + propolis (AP); $* \mathrm{p}<0.05 ; * * \mathrm{p}<0.01 ; * * * \mathrm{p}<0.001$

Regarding the IL-18 levels, we found that this cytokine was predominant in the GCF in adolescents with gingivitis. IL-18 concentrations were 6 to 20 times higher than the rest of the cytokines included in our study. Similar results were reported by other authors [15]. IL-18 could be found in gingivitis and periodontitis sites and its concentration increases with the periodontal disease progression. This is not surprising, given the role of this cytokine in the bone resorption process. IL-18 activates the matrix metalloproteinase-9 and IL-1 $\beta$ and is involved also in the chronic periodontal inflammation [18]. In our study, IL-18 levels were significantly reduced in the group AP in comparison to group A after the 20 days period of treatment.

We strongly agree with Pradeep et al. [18] that IL18 could be used as a biomarker of periodontal inflammation.
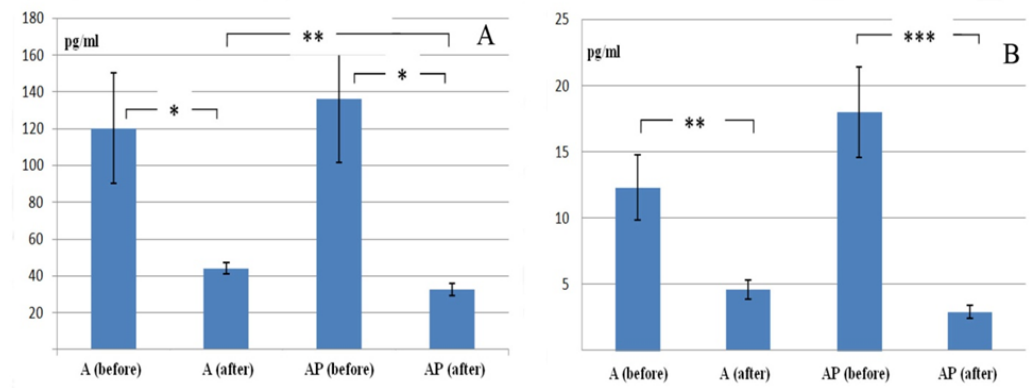

Figure 3.

Mean concentrations ( \pm SEM) of IL-18 (A) and INF- $\gamma(B)$ in gingival crevicular fluid before and after 20 days of treatment with toothpaste (A) or toothpaste + propolis (AP); ${ }^{*} \mathrm{p}<0.05 ; * * \mathrm{p}<0.01 ; * * * \mathrm{p}<0.001$

IL-18 in the presence of IL-12 increases the production of INF- $\gamma$ in T-cells [15]. INF- $\gamma$ activates the neutrophils and macrophages, leading to enhanced phagocytosis [7]. Papathanasiou et al. 
FARMACIA, 2019, Vol. 67, 2

[16] compared the concentration of INF- $\gamma$ in diseased sites in patients with gingivitis and healthy sites in patients with periodontitis and reported a significant decrease. They propose that INF- $\gamma$ concentration depends on the presence of inflammation in the site. Our results support this hypothesis and both therapeutical approaches resulted in decreased levels of this cytokine at the end of the study, when the inflammation was reduced (data not shown).

The first approach (brushing with marketed toothpaste for 20 days; group A) led to a significant reduction in the levels of IL-1 $\beta$ (Figure 1A), TNF- $\alpha$ (Figure 2A), IL-18 (Figure 3A) and INF- $\gamma$ (Figure $3 \mathrm{~B})$. A tendency of decrease was observed also in the levels of IL-6 (Figure 1B) and IL-17 (Figure 2B), but it didn't reach the level of significance.

The second therapeutical approach (adding propolis to the toothpaste before brushing the teeth; group AP) resulted in a significant decrease in all studied cytokines. This approach also resulted in significantly lower levels of IL-1 $\beta$ and IL-18 in comparison with the first one (group A) on the $20^{\text {th }}$ day of the treatment. The concentrations of the other cytokines were also lower in the AP group at the end of the experiment when compared to group A, however, the difference was nonsignificant.

\section{Conclusions}

In conclusion, IL-18 and IL-1 $\beta$ could be used as inflammatory biomarkers in adolescents with gingivitis. The addition of Propolin $^{\circledR}$ to the toothpaste resulted in a reduction of the gingival inflammation in adolescents with moderate gingivitis and greater gingival health improvement than the sole use of a toothpaste. The high levels of galangin, pinocembrin, chrysin, and caffeic acid esters in propolis could be related to its therapeutic effects on gingivitis.

\section{Conflict of interest}

Authors declare no conflict of interest.

\section{Acknowledgement}

This study received funding from Medical University - Plovdiv (grant number NO3/2010).

\section{References}

1. Apostolova E, Kokova V, Peychev Z, Peycheva S, Apostolov A, Effect of fucoidan, Haberlea rhodopensis and propolis on mobilization of the CD34+ stem cells in rats. Farmacia, 2017; 65(4): 567-570.

2. Bankova V, Popova M, Bogdanov S, Sabatini A, Chemical composition of European propolis:
Expected and unexpected results. Zeitschrift für Naturforschung, Teil C, 2002; 57: 530-533.

3. Bendtzen $\mathrm{K}$, Cytokine and natural regulators of cytokine. Imunol Lett., 1994; 43: 111-123.

4. Boronat-Catalá M, Catalá-Pizarro M, Bagán Sebastián JV, Salivary and crevicular fluid interleukins in gingivitis. J Clin Exp Dent., 2014; 6: 175-179.

5. Cobb CM, Microbes, inflammation, scaling and root planing, and the periodontal condition. $J$ Dent Hyg., 2008; 82: 4-9.

6. Ercan N, Erdemir EO, Ozkan SY, Hendek MK, The comparative effect of propolis in two different vehicles; mouthwash and chewing-gum on plaque accumulation and gingival inflammation. Eur $J$ Dent., 2015; 9: 272-276.

7. Gemmel E, Seymor GJ, Immunoregulatory control of the Th1/Th2 cytokine profiles in periodontal disease. Periodontol 2000, 2004; 35: 21-41.

8. Gonzáles JR, Herrmann JM, Boedeker RH, Francz PI, Biesalski H, Meyle J, Concentration of interleukin-1beta and neutrophil elastase activity in gingival crevicular fluid during experimental gingivitis. J Clin Periodontol., 2001; 28: 544-549.

9. Hasturk H, Kantarci A, Van Dyke TE, Oral inflammatory diseases and systemic inflammation: role of the macrophage. Front Immunol., 2012; 3:117.

10. Hazem A, Popescu C, Crişan I, Popa M, Chifiriuc M, Pircalabioru G, Lupuliasa D, Antibacterial efficiency of five propolis extracts on planktonic and adherent microbial strains. Farmacia, 2017; 65(5): 813-818.

11. Hazem A, Pitică-Aldea I, Popescu C, Matei L, Dragu D, Economescu M, Alexiu I, Crişan I, Diaconu C, Bleotu C, Lupuliasa D, The antiviral/virucidal effects of alcholic and aqueous extracts with Propolis. Farmacia, 2017; 65(6): 868876.

12. Kamma J, Mombelli A, Tsinidou K, Vasdekis V, Giannopoulou C, Cytokines in gingival crevicular fluid of adolescents and young adults. Oral Microbiol Immunol., 2009; 24: 7-10.

13. Löe H, The Gingival Index, the Plaque Index and the Retention Index Systems. J Periodontol., 1967; 38(6 Suppl): 610-616.

14. Noh MK, Jung M, Kim SH, Lee SR, Park KH, Kim DH, Kim HH, Park YG, Assessment of IL-6, IL-8 and TNF- $\alpha$ levels in the gingival tissue of patients with periodontitis. Exp Ther Med., 2013; 6: 847851.

15. Orozco A, Gemmell E, Bickel M, Interleukin-1 $\beta$, interleukin-12 and interleukin-18 levels in gingival fluid and serum of patients with gingivitis and periodontitis. Oral Microbiology Immunology, 2006; 21: 256-260.

16. Papathanasiou E, Teles F, Griffin T, Arguello E, Finkelman M, Hanley J, Theoharides TC, G ingival crevicular fluid levels of interferon- $\gamma$, but not interleukin-4 or-33 or thymic stromal lymphopoietin, are increased in inflamed sites in patients with periodontal disease. $J$ Periodontal Res., 2014; 49: 55-61. 
17. Petersen PE, Hoerup N, Poomviset N, Prommajan $\mathrm{J}$, Watanapa A, Oral health status and oral health behaviour of urban and rural schoolchildren in Southern Thailand. Int Dent J., 2001; 51: 95-102.

18. Pradeep A, Hadge P, Exploring the role of Th1 cytokines: IL-17 and IL-18 in periodontal health and disease. J Oral Sci., 2009; 51; 2: 261-266.

19. Slavov A, Trifonov A, Peychev L, Dimitrova S, Peycheva S, Gotcheva V, Angelov A, Biologically active compounds with antitumor activity in propolis extracts from different geographic regions. Biotechnol Biotechnol Equip., 2013; 27: 4010-4013.

20. Slavov A, Denev P, Panchev I, Shikov V, Nenov $\mathrm{N}$, Yantcheva N, Vasileva I, Combined recovery of polysaccharides and polyphenols from Rosa damascena wastes. Ind Crops Prod., 2017; 100: 85-94.

21. Tatikonda A, Debnath S, Chauhan VS, Chaurasia VR, Taranath M, Sharma AM, Effects of herbal and non-herbal toothpastes on plaque and gingivitis: A clinical comparative study. J Int Soc Prevent Communit Dent., 2014; 4(2Suppl): 126-129.

22. Woo KJ, Jeong YJ, Inoue H, Park JW, Kwon TK, Chrysin suppresses lipopolysaccharide-induced cyclooxygenase- 2 expression through the inhibition of nuclear factor for IL-6 (NF-IL6) DNA-binding activity. FEBS Lett., 2005; 579: 705-711. 